\title{
Bioecological properties of underground pests in cultivation of potatoes planted after grain
}

\author{
Azamjon Khudoykulov ${ }^{1, *}$, Azimjon Anorbaev ${ }^{1}$, and Gulnoza Kholikova ${ }^{1}$ \\ ${ }^{1}$ Tashkent State Agrarian University, University str., 2, Tashkent province, Uzbekistan, 100140
}

\begin{abstract}
In the conditions of Tashkent and Samarkand provinces of Uzbekistan, autumn moth (Agrotis segetum Den. Et Sshiff) is one of the most common pests in irrigated agricultural areas. The worms of this pest damage hundreds of crops belonging to 34 families and infect cotton, alfalfa, sugar beet, corn, cereals, legumes, oilseeds and vegetables, melons and potatoes, as well as ivy, wild coconut, sorghum, and oats. Autumn nocturnal worms pierce the seed pods, damaging the root collar of young sprouting crops. The developmental characteristics of underground pests of potatoes planted in the post-grain recurrence period were studied, their bioecology according to the characteristics of damage to various crops.
\end{abstract}

\section{Introduction}

It is urgent to develop effective and fundamentally based control measures against agricultural pests in the world in order to preserve the lost crops. In this regard, the expansion of effective biological methods of pest protection and control of cereals and vegetables and potatoes requires further improvement of existing biological control technologies, in particular, the introduction of intensive methods of searching and production of effective entomophagous species in vegetable crops [1,2].

Due to the harmful effects of pests and diseases on agricultural crops, $30-40 \%$ of crops are lost each year [3]. Despite the timely control of these pests, the management of their numbers remains relevant today [4]. In particular, food security has significantly increased the number of rodents and sucking pests in Europe and southeastern and western Africa during the growing season $[2,4,5]$.

In order to ensure uninterrupted and full supply of food products to the population of the republic, Uzbekistan pays special attention to the cultivation of cereals, vegetables and potatoes, increasing the range of products from these crops, as well as increasing the income of the rural population $[6,7]$.

In recent years, as a result of damage to the root system and sprouted grasses of legumes, vegetables and potatoes during the young growing season due to the damage of underground pests in Uzbekistan, the seedlings are in conflict and cause the death of the plant. This leads to a sharp decrease in yield and deterioration of product quality [1].

In the cultivation of agricultural crops, representatives of the subspecies (Leridoptera) and (Soleoptera) families of groundwater pest species are common and cause great damage

\footnotetext{
* Corresponding author: azamjon.khudoykulov@yandex.com
} 
to plants. Where these ground pests are not controlled, it can destroy $60-70 \%$ of vegetable crops in years of mass multiplication, especially $25-30 \%$ of replanted potatoes $[8,13,15]$. Criteria for the economically harmful amount of subterranean pests were determined in vegetable crops, cotton and other crops under field conditions [9, 12, 14]. These subterranean pests have been reported as the main pests of all vegetable and potato crops in Central Asia and Europe [2, 3].

In recent years, as a result of damage by root rodent pests, legumes, vegetables and potato crops damage the root portion and sprouted grasses during the young germination period, causing the seedlings to clash and the plant to die. This leads to a sharp decrease in yield and deterioration of product quality $[10,11]$.

Autumn moth (Agrotis segetum Den. Et Sshiff) is one of the most common pests in irrigated farming areas. The worms of this pest damage hundreds of crops belonging to 34 families. Cotton, alfalfa, sugar beet, corn, cereals, legumes, oilseeds and vegetables, melons and potatoes, as well as ivy, wild coconut, sorghum, alfalfa are the favorite foods of autumn moth. Autumn nocturnal worms pierce the seed pods, damaging the root collar of young sprouting crops. At the same time it eats the roots or stems near the root collar, sometimes even damaging the surface of the grass $[16,17]$.

Agrotis exclamations Den. Et Shiff is a common species, usually second only to the autumn tsunami in terms of multi-infestation. Nightworms infect 75 species of plants, including cereals, tobacco, hemp, corn, cotton, sunflowers, sugar beets, legumes, vegetables and potatoes [18].

At the base of its front wings, a spot reminiscent of an exclamation mark is clearly visible, and its name is given to the same sign. This pest, unlike the autumn moth, leaves offspring twice a year. Morphological features and survival are very similar to those of the autumn night $[5,8,9]$.

Based on the above, research was conducted to study the bioecology of the development of autumn and fallow moths from underground pests on potatoes planted repeatedly in the conditions of Samarkand and Tashkent provinces of Uzbekistan.

\section{Materials and methods}

From root-eating pests in potato crops re-planted in Samarkand and Tashkent provinces of Uzbekistan; the bioecology of the species composition, distribution area, and degree of damage of root-eating rodents was studied. The soil was excavated to account for insects living in the soil. Excavation was carried out once every 10 days. The soil was slowly excavated at a level of $0.25 \mathrm{~m} 2$ and sieved, and all insects were collected, and samples were taken from 10 sites in a total area of 1.0 ha.

The study was conducted in a potato field in 2017-2018 to determine the biological efficacy of insecticides against autumn and weevil moths, which are the dominant species among root rodent moths. Phenological observations were made on the tunnels, their timing of overwintering, egg laying, and emergence of a new generation were studied [1,3]. Light traps (BUF-30) and pheromone traps were used to control the flight of butterflies in the autumn and midnight $[4,5]$.

Entomological hairs (entomological hairs) were used to collect insects in the field. Collected insects bring other pests to the "Biological Protection Center" of plants, a biological microscope that magnifies those 5, 10, 20, 40, 60 and 100 times (MBS-1) and were determined using hand magnifiers showing different sizes of hands.

Observations were made to determine the emergence and prestige of autumn and late blight worms and the effectiveness of chemicals in the fully germinated potato field in the experimental field. The size of the registration area was $1 \mathrm{~m}^{2}$ and chess samples were taken from 10 places in the field. 
In the study, the density of species in the agrobiocenosis was determined by calculating the average amounts of $1 \mathrm{~m}^{2}$ of autumn and winter moth (calculated separately in and around the field). Research based on the methodological guidelines of SH. T. Khodjaev and the biological effectiveness of the methods and tools used, the equation of Abbott (1925) was determined $[6,7,10]$.

\section{Results and discussion}

In order to study the stages of development and damage of eggs and larvae of butterflies in the potato crop, we conducted research on a 1.5-hectare replanted potato field of the farm "Salim Vahobov" Bulungur district of Samarkand province.

He was planted in the experimental field after the selection of Santa varieties. In the potato field, which was planted on June 15, 2017 and fully germinated on July 1, sexual pheromone traps of autumn and fallow moth were installed and the flight of pest butterflies was taken into account.

The results showed that in the newly sprouted potato field, the fall of autumn moths on the stalks on July 5 averaged 9.0 per stalk, compared to 0.5 on the 10 th day of the calculation day.

Thus, the flight dynamics of autumn moths was observed to decrease in the second half of August. A similar situation was observed in the handles on which sex pheromones were induced. While the number of moths was 2.1 per day, our observations showed a slight decrease to 10 days $(0.1)$ (Table 1$)$.

Table 1. Autumn and attractive moths fall into sexual traps

("Salim Vahobov" farm, Bulungur district, Samarkand province, 'Santa navi' variety planting period, June 15, 2017-2018)

\begin{tabular}{|c|c|c|c|c|c|c|c|c|c|c|c|c|}
\hline \multirow[b]{2}{*}{ Pest } & \multicolumn{10}{|c|}{ Average number of butterflies per 1 catch on control days, pes } & \multirow{2}{*}{ 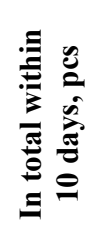 } & \multirow{2}{*}{ 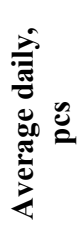 } \\
\hline & $\begin{array}{l}n \\
\stackrel{2}{\Xi}\end{array}$ & $\begin{array}{l}b \\
\grave{\Xi} \\
\grave{\Xi}\end{array}$ & $\stackrel{\wedge}{\grave{\Xi}}$ & $\begin{array}{l}\infty \\
\grave{\Xi} \\
\grave{\Xi}\end{array}$ & 彥 & $\frac{0}{\frac{2}{2}}$ & $=$ & $\frac{\mathfrak{Z}}{\underline{B}}$ & $\frac{2}{3}$ & $\frac{\Delta}{\frac{\lambda}{\Xi}}$ & & \\
\hline $\begin{array}{c}\text { Autumn } \\
\text { moth }\end{array}$ & 9.0 & 7.0 & 6.5 & 5.2 & 4.2 & 4.0 & 3.5 & 2.0 & 1.2 & 0.5 & 43.1 & 4.3 \\
\hline $\begin{array}{l}\text { Attractive } \\
\text { moth }\end{array}$ & 2.1 & 2.0 & 1.6 & 1.5 & 1.2 & 1.0 & 0.7 & 0.5 & 0.3 & 0.1 & 11.0 & 1.1 \\
\hline
\end{tabular}

In order to determine the emergence and prevalence of autumn and attractive moth worms in fully germinated seedlings in the potato field, observations were continued. According to him, the average number of autumn night worms in the potato field was 0.3 per $1 \mathrm{~m}^{2}$, in the first decade of July an average of 0.3 , in the 2 nd decade 0.5 , and in the $3 \mathrm{rd}$ decade 0.8 . These values are proportional to 0.2 for urticaria worms; 0.7 and 0.8 , respectively (Table 2). 
Table 2. Amount of autumn and attractive moths in the potato field ("Salim Vahobov" farm, Bulungur district, Samarkand province, sowing period of "Santa navi" potatoes, June 15, 2018-2019)

\begin{tabular}{|c|c|c|c|c|c|c|}
\hline \multirow{3}{*}{$\begin{array}{c}\text { Control } \\
\text { quadrats } 1 \mathrm{~m}^{2}\end{array}$} & \multicolumn{6}{|c|}{ July } \\
\hline & \multicolumn{2}{|c|}{$1^{\text {st }}$ decade } & \multicolumn{2}{|c|}{$2^{\text {nd }}$ decade } & \multicolumn{2}{|c|}{$3^{\text {rd }}$ decade } \\
\hline & Larva & Egg & Larva & Egg & Larva & Egg \\
\hline$\# 1$ & 0.4 & 0.6 & 0.8 & 1.0 & 1.2 & 1.5 \\
\hline \#2 & 0.2 & 0.4 & 0.1 & 0.6 & 0.7 & 1.1 \\
\hline$\# 3$ & 0.1 & 0.4 & 0.1 & 0.4 & 0.6 & 1.1 \\
\hline \#4 & 0.5 & 0.8 & 0.1 & 0.5 & 0.8 & 1.2 \\
\hline$\# 5$ & 0.2 & 0.4 & 0.7 & 1.1 & 0.8 & 1.1 \\
\hline$\# 6$ & 0.3 & 0.4 & 0.8 & 1.2 & 0.9 & 1.3 \\
\hline$\# 7$ & 0.2 & 0.3 & 0.6 & 0.9 & 0.6 & 0.9 \\
\hline Average & 0.3 & 0.4 & 0.5 & 0.7 & 0.8 & 1.2 \\
\hline
\end{tabular}

The average number of autumn night eggs was 0.4 per $1 \mathrm{~m}^{2}$ in the first decade of July, 0.7 in the 2 nd decade, and 1.2 in the 3 rd decade. It can be observed that the number of pest worms has increased.

In order to monitor the development of moth in other areas, the study was conducted in the potato field planted after the grain of the farm "Faradis Hirmoni" in Yukori Chirchik district of Tashkent province. Potato seeds were sown on July 15, coinciding with the germination period of potato development (Table 3).

Table 3. Number of autumn and attractive moths in the potato field ("Faradis Hirmoni" farm, Yukori Chirchik district, Tashkent province, planting date of 'Santa Navi' potatoes, July 15, 2017-2018)

\begin{tabular}{|c|c|c|c|c|c|c|}
\hline \multirow{2}{*}{$\begin{array}{c}\text { Control } \\
\text { quadrats 1 }\end{array}$} & \multicolumn{7}{|c|}{ July } \\
\cline { 2 - 7 } & \multicolumn{2}{|c|}{$\mathbf{1}^{\text {st }}$ decade } & \multicolumn{2}{|c|}{$\mathbf{2}^{\text {nd }}$ decade } & \multicolumn{2}{|c|}{$\mathbf{3}^{\text {rd }}$ decade } \\
\cline { 2 - 7 } & Larva & Egg & Larva & Egg & Larva & Egg \\
\hline$\# 1$ & 0.9 & 1.2 & 1.5 & 2.0 & 2.5 & 3.1 \\
\hline$\# 2$ & 1.1 & 1.4 & 2.0 & 2.2 & 2.1 & 2.4 \\
\hline$\# 3$ & 0.7 & 1.0 & 0.8 & 1.2 & 1.5 & 1.8 \\
\hline$\# 4$ & 0.6 & 1.0 & 2.1 & 2.5 & 1.4 & 1.7 \\
\hline$\# 5$ & 1.0 & 1.3 & 1.5 & 1.9 & 2.8 & 3.3 \\
\hline$\# 6$ & 0.6 & 0.9 & 1.9 & 2.3 & 2.9 & 3.1 \\
\hline$\# 7$ & 0.9 & 1.1 & 1.8 & 2.3 & 3.2 & 3.5 \\
\hline Average & 0.8 & 1.3 & 1.6 & 2.5 & 2.3 & 2.7 \\
\hline
\end{tabular}

According to the table above, 7 samples were taken in 3 turns on the diagonal of the crop area. According to the observed samples, the average number of autumn night worms was 0.8 in the 1 st decade of August, 1.6 in the 2 nd decade, and 2.3 in the 3 rd decade. The average number of autumn night eggs was 1.3 per $1 \mathrm{~m}^{2}$ in the 1 st decade of July, 2.5 in the 2nd decade, and 2.7 in the 3 rd decade.

The study concluded that the main reason for the relatively low number of root-knot worms in the replanted potatoes on 15 June compared to the replanted potatoes on 15 July was that the germination of replanted potato grasses in the evening coincided with many flight periods of night moths. This has led to an increase in the amount of pest and an increase in density in replanted crops.

The influx of wheat into the structure of agricultural crops and the planting of maize and other vegetable crops as a secondary crop after wheat causes the habitats of many pests, 
including autumn and aphids, to vary throughout the season $[11,12]$. During the season, we conducted observations in different areas of Jambay district of Samarkand province in 2017-2018 in order to study the feeding stations, survival and species ratio of autumn and winter moth.

In our study, root rot worms and fungi were collected from lands where winter wheat was planted in April (for the first generation), as well as cotton, corn, and potatoes planted the previous year. The non-fungal worms were supplemented under laboratory conditions, and butterfly flight was observed after the fungus had evolved. In the same way, from midMay to the end of June, the next generation of worms were collected in the new crop fields, and their viability and species were studied (Table 4).

Table 4. Survival of subsurface sediments in primary and secondary crops (Jambay district of Samarkand province, 2017-2018)

\begin{tabular}{|c|c|c|c|c|c|c|}
\hline \multirow[b]{3}{*}{ 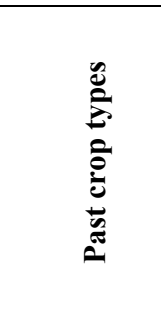 } & \multirow{3}{*}{ 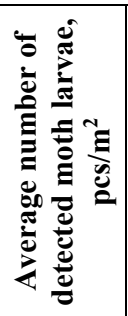 } & \multirow{3}{*}{ 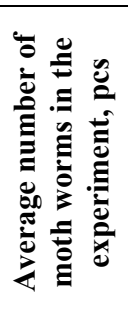 } & \multicolumn{4}{|c|}{ Maturated butterfliese } \\
\hline & & & \multirow{2}{*}{ Total } & \multicolumn{3}{|c|}{ By species, $\%$} \\
\hline & & & & 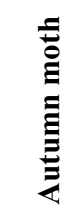 & 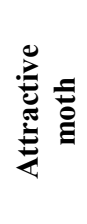 & 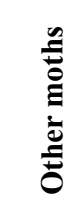 \\
\hline \multicolumn{7}{|c|}{ Overwintered generation } \\
\hline $\begin{array}{l}\text { Winter } \\
\text { wheat }\end{array}$ & 1.7 & 100 & 94.1 & 68.2 & 21.2 & 10.6 \\
\hline $\begin{array}{l}\text { Cotton after } \\
\text { cotton }\end{array}$ & 0.3 & 100 & 81.3 & 56.4 & 26.7 & 16.9 \\
\hline $\begin{array}{c}\text { Cotton after } \\
\text { maize }\end{array}$ & 2.6 & 100 & 91.2 & 59.5 & 25.6 & 14.9 \\
\hline $\begin{array}{c}\text { Cotton after } \\
\text { potato }\end{array}$ & 1.9 & 100 & 93.5 & 61.2 & 22.8 & 16.0 \\
\hline \multicolumn{7}{|c|}{ New generation } \\
\hline $\begin{array}{l}\text { Winter } \\
\text { wheat }\end{array}$ & 0.1 & 100 & 88.4 & 76.5 & 5.6 & 17.9 \\
\hline $\begin{array}{c}\text { Cotton after } \\
\text { cotton }\end{array}$ & 0.3 & 100 & 92.1 & 78.2 & 7.3 & 14.5 \\
\hline $\begin{array}{c}\text { Cotton after } \\
\text { maize }\end{array}$ & 0.5 & 100 & 90.3 & 84.3 & 6.1 & 9.6 \\
\hline $\begin{array}{c}\text { Cotton after } \\
\text { potato }\end{array}$ & 0.4 & 100 & 93.2 & 88.1 & 5.8 & 6.1 \\
\hline
\end{tabular}

According to the results, in April, the average density of winter root rot per $1 \mathrm{~m}^{2}$ of sown area was 1.7 pieces in the area sown with winter wheat, 0.3 pieces in the area sown after cotton, 2.6 pieces in the area sown after corn, 2.6 pieces in the area sown after late potatoes or in the cotton field was 1.9 pieces. The population of new (second) generation worms was low in these crops, averaging $0.1-0.5$ per $1 \mathrm{~m}^{2}$ of crop area. The main reason for this is that at this time the body of wheat and cotton crops hardens, which is not conducive to feeding pests.

Therefore, the second generation of root rot rodents thrives on more vegetables and other relatively late crops. 
When we studied the viability of worms collected in early spring after various past crops, the survival rate of wintering night worms was $94 \%$ in the wheat field, $81 \%$ in the post-cotton field, $91 \%$ in the corn-free field, and $93 \%$ in the evening potato field.

When we studied the species composition of wintering root rodents at different stages of development, it was found that $68.2 \%$ of wintering rodents in the winter wheat field were autumn moths, $21.2 \%$ were urticaria moths, and $10.6 \%$ were other root rodent moths.

\section{Conclusion}

Summarizing all results above, in April, the average density of winter root rot per $1 \mathrm{~m}^{2}$ of sown area was 1.7 pieces in the area sown with winter wheat, 0.3 pieces in the area sown after cotton, 2.6 pieces in the area sown after corn, 2.6 pieces in the cotton area sown after potatoes was 1.9 pieces. The population of new (second) generation worms was low in these crops, averaging $0.1-0.5$ per $1 \mathrm{~m}^{2}$ of crop area.

\section{References}

1. S. Isaev, I. Begmatov, G. Goziev, S. Khasanov, IOP Publishing 883(1), 012080 (2020)

2. S. K. Isaev, R. U. Rakhmonov, S. S. Tadjiev, G. I. Goziev, S. Z. Khasanov, IOP Publishing 614(1), 012147 (2020)

3. S. Alimuhammedov, SH. Khujaev, Cotton pests and combatting with them, 37-45 (Ukituvchi Press, Tashkent, 1991)

4. P. Caballero, E. Vargas-Osuna, C. Santiago-Alvarez, Journal of Applied Entomology 115(1-5), 59-64 (1991)

5. P. Ebsjerg, Journal of Applied Entomology 105(1-5), 295-302 (1988)

6. P. Esbjerg, Journal of Applied Entomology 102(1-5), 277-285 (1986)

7. P. Esbjerg, L. Sigsgaard, Crop Protection 62, 64-71 (2014)

8. J. Garnis, Z. Browski, Vegetable Crops Research Bulletin 68, 81-91 (2008)

9. M. Jakubowska, J. Bocianowski, Journal of Plant Protection Research 3(53), 215-221 (2013)

10. A. Kholliev, International Journal of Scientific and Technology Research 12(8), 19061908 (2019)

11. S. M. Haldhar, G. C. Jat, H. L. Deshwal, J. S. Gora, D. Singh, Towards Organic Agriculture, 359-390 (2017)

12. C. Löfstedt, Journal of Chemical Ecology 8(10), 1305-1321 (1982)

13. S. Gazi, I. Safarova, Entomol Journal, 18 (2018)

14. I. Nyamwasa, Crop Protection 106, 163-176 (2018)

15. S. Labaude, C. T. Griffin, Insects 9(2), 72 (2018)

16. A. M. Reynolds, Journal of Theoretical Biology 245(1), 141-149 (2007)

17. M. G. E. Svensson, E. Marling, J. Löfqvist, Journal of Insect Behavior 11(3), 343-359 (1998)

18. A. Sevim, Z. Demirbag, I. Demir, Turkish Journal of Agriculture and Forestry 34(4), 333-342 (2010) 